\title{
The Blended Learning Model for Orthopedagogic of Children With Physical Disability Course
}

\author{
Endang Pudjiastuti Sartinah \& Sri Joeda Andajani \\ Faculty of Education \\ Universitas Negeri Surabaya \\ Surabaya, Indonesia \\ endangsartinah@unesa.ac.id sriandajani@unesa.ac.id
}

\begin{abstract}
The aim of this research is to produce prototype of blended learning model product for orthopedagogic of children with physical disability course in special education department. This development research used ADDEM design (Analyze, Design, Develop, Deliver, Evaluate, and Maintenance). In this research, the prototype product of blended learning model for orthopedagogic of children with physical disability course in special education department is classified into 2 ways, that is offline in the form of textbook product, and online in the form of e-material of service process of activities of dailly living (ADL), and children with physical disability auxiliary tools programmed through virtual learning. The prototype products are produced as an effort to facilitate lectures of undergraduate students majoring in special education.
\end{abstract}

Keywords-Blended Learning Model; Orthopedagogic of Children with Physical Disability

\section{INTRODUCTION}

Learning as a series of activities designed to enable the learning process to occur in students. In learning is used to show the activities of educators and students. Likewise learning shows the interaction of students which is not limited by the presence of educators physically. Students can learn through printed teaching materials, audio and video programs, television, radio, and / or other media based on ICT (Information and Communition Technology). But of course, educators still play an important role in designing every learning activity in the classroom.

Affirmation of learning as an effort for students to learn, and the learning process as a linking of new knowledge to the cognitive structure that has been owned by the learners. However, learning is a systematic and systemic effort to initiate, facilitate, and improve the learning process. In learning activities are closely related to the type of nature and type of learning and learning outcomes. Although learning results in learning, not all learning processes occur because of learning. But this learning is in the context of formal education, namely education in universities or institutions and occurring in the classroom.

The basic concept of learning in article 1 point 20 of Law Number 20 of 2003, on Indonesia's National Education System mentioned that "Learning is the process of interaction of learners with educators and learning resources in the learning environment". In this concept contained 5 concepts, including: interaction, learners, educators, learning resources, and learning environment.

Mainstreaming of learning above, shows that the main characteristics of learning is the initiation, facilitation, and improvement of learner's learning process. This shows that learning has the element of deliberate outsiders who do the learning process. It is individual educators or collective in a system as the main characteristic of the concept of learning. Trianto (2007: 15) suggests that good learning is a lesson that emphasizes the full involvement of learners and educators, so that it will create conditions in which all process can achieve the desired quality.

The realization is affirmed in the Government Regulation No. 19 Year 2005 on National Standards of Education, especially in Chapter IV Article 19 which suggests that the learning process in educational units is held interactively, inspirative, fun, challenging, motivate learners to participate actively, and provide sufficient space for initiative, creativity and independence in accordance with talent, interest and physical development and psychological conditions of learners. The embodiment as a form of inspiration in the way of developing teaching materials for orthopedagogic of children with physical disability. Innovation of learning as a demand of a conventional nature of information and communication technology in line with the demands of the global era.

Form the design of devices/ equipment that can be visualized and sounded that is packaged through the empowerment of learning resources based on information and communication technology or ICT. Therefore the development of teaching materials for orthopedagogic of children with physical disability course in Special Education Department was choosen because it has the uniqueness of various characteristics during the learning process.

Faisal (2011) argued through the findings about blended learning opportunity to shift the paradigm of conventional learning toward information and communication technology in developing new knowledge, skills, and behavior for learners. In blended learning as a process, teaching and learning activities require a variety of methods, models and instructional media applied to achieve maximum results and quality. Smaldino, et al implied (2011: 11) that learning develops new knowledge, skills, and behaviors that are individual interactions with information and the environment. The skills of information 
technology and communications require not only technical skills but also demands mental maturity and problem-solving abilities. Moreover, classroom learning uses information and communication technology with media packaging that can be visualized and sounded the acquisition of effective learning behaviors.

Educators or lecturers who control, lead and direct teaching events. Degeng (2000) explained, that the three components in describing the delivery strategy in learning, consist of: a) learning media, b) student interaction with media, and c) form of teaching and learning. Emphasis the lies on classroom learning system, view learners in heterogeneous groups with their various characteristics and learning materials. The other side of the orthopedagogic of children with physical disability course, facilities to support online procurement at the State University of Surabaya has been developed, but the implementation is still not maximized.

Especially in the orthopedagogic of children with physical disability course the foundation requires an understanding that is not only fixed on the form of learning that still uses images (non multimedia). The other side of the course is the orthopedagogic of children with physical disability course, most of which are subjects that require a comprehensive picture of the condition of various disabilities of different characteristics and needs. The problems mentioned above require the development of a blended learning model for orthopedagogic of children with physical disability course in special education department so the purpose of this study is to produce the product prototype of blended learning model for orthopedagogic of children with physical disability course in Special Education Department.

\section{METHOD}

As for developing this teaching materials by adapting the model of ADDDEM through 6 stages, namely Analyze, Design, Develop, Deliver, Evaluate, and Maintenance (Pramono, Made, et al, 2015).Development of ADDDEM as one type of development to design models of blended learning in the orthopedagogic of children with physical disability course shaped based off line and online on Special Education Depatment Faculty of Education State University of Surabaya. In this research development used 6 step cycles as the basis for producing products packed through dictate and e-material book forms. Textbook products in mobile movement and mobility learning are packaged offline and e-material teaching materials are packaged online. The development of ADDDEM for the manufacture of products models blended learning as a resource, is shown in figure 1.

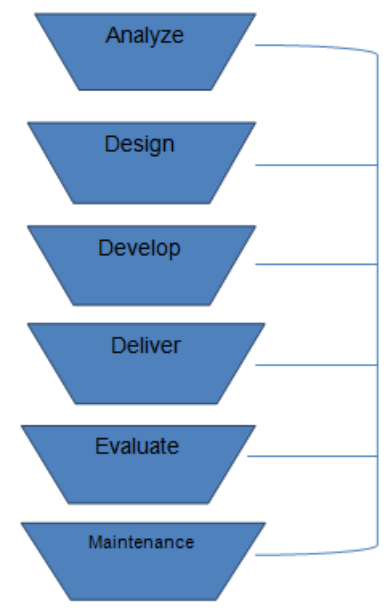

Fig. 1. Research Process

Data at prototype stage of blended learning model on orthopedagogic of children with physical disability course werw collected through questionaire developed to gather expert opinion on the feasibility of the model of blended learning seen from three aspects include: usability, feasibility, and accuracy.

Quantitative data obtained from expert tests and user tests were analyzed based on the criteria provided by experts and prospective users with 4 categories of answers as listed in the questionnaire(values $1,2,3$, and 4), which were then converted in per centage form. Conversion results are based on opinions by Cronbach (1990):

- $0 \%-64 \%=1$, very less precise / less obvious / less appropriate, revised.

- $65 \%-79 \%=2$, less precise / less obvious / less appropriate, revised.

- $80 \%-89 \%=3$, exact / clear / appropriate, unrevised.

- $90 \%-100 \%=4$, very precise / very clear / very appropriate, not revised.

\section{RESULTS AND DISCUSSION}

A. Result

1) Product development process of prototype blended learning model for orthopedagogic of children with physical disability course in special education department

At this stage of the process of blended learning model for for orthopedagogic of children with phys-ical disability course in special education depart-ment, referring to the development research ADDEM model (Analyze, Design, Develop, Deliver, Evaluate, and Maintenance), are as follows:

\section{a) Analyze}

At this stage as a preliminary execution for the search and gathering of information developed through analyze the competence of the course by consid-ering the principle of 
reuse andrepurpose, so it can be described as loose objects (learning objects) that are shareable and reuseable.

\section{b) Design}

The development of teaching materials of blended learning model for orthopedagogic of children with physical disability course in special education de-partment starting with determining and then followed by (1) defines the learning object (LO) at each level (2) defines the prerequisites and competencies of each learning object (LO) (3) defines the relation of each learning object (LO) (4)designing learning object metadata (LO) (5) designing the object learning strategy (LO) (6) Designing LO learning media (7) Enhance competence, training and assessment.

In designing instructional materials through learning object strategy in orthopedagogic of children with physical disability course in are forced to use blended learning models of packaging offline and online. Offline learning object strategy is designed in the form of textbooks for orthopedagogic of children with physical disability containing 100 sheets pages, with cover is shown in the figure 2 bellow:

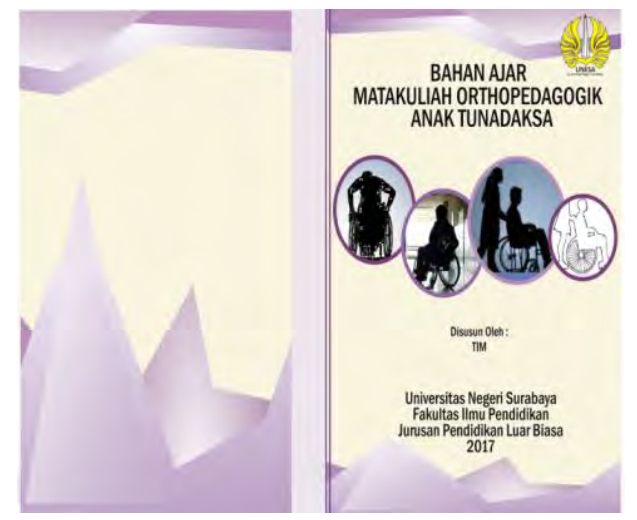

Figure 2. Book Cover

c) Develop

- Develop e-materials by applying reuse and repur-pose LOs at each level, as well as reuse and repur-pose objects of information and digital assets (identifying new content and existing content).

- Developing e-materials using technologies that are neutral to the delivery method.

- Developing e-materials using technology that is device independent.

- Packaging e-materials follows the e-learning standard specification.

d) Deliver

- Apply internet technology to e-mail items with various formats.

- Implement mobile technology to e-materials.

\section{e) Evaluate}

At this stage is done at each stage at up and function like feedback to correct any possible errors. Here are the steps at this stage.
- LO approach, to feed back between fellow lectur-ers and students to reuse / repurpose the learning ob-ject (LO)

- Evaluating learning object (LO)

- Evaluate metadata

\section{f) Maintenance}

This stage is done to maintain the relevance of e-material in the orthopedagogic of children with physical disability course in special education de-partment, here are the steps that can be taken.

- Keeping e- content content always relevant,

- Keep the e-material content is always up-todate,

- Utilizing evaluation data for material repair or maintenance of e-material content.

\section{B. Discussion}

The effectiveness of learning aspect is usually meas-ured by the level of achievement of the learners on a more defined learning objective. Efficiency is usual-ly measured by the ratio between effectiveness and the amount of time and / or cost spent, while the at-tractiveness of learning is usually measured by ob-serving the learner's tendency to continue learning. Furthermore, Degeng (2000) argued that the results of learning usually follow certain lessons that must be associated with the achievement of learning ob-jectives that have been determined. In line with this Setyosari (2006), said that effective learning empha-sizes the importance of learning as a personal pro-cess, and contains learning strategies that can accommodate multiple contexts, learners with diverse backgrounds, needs and problems.

Based on this reality, the development of prototype product of blended learning model for orthopedagogic of children with physical disability course in special education departmen as a solution in learning cognitive understanding and practice and attitude for learning innovation. The process of developing a prototype product of the blended learning model for orthopedagogic of children with physical disability course in special education departmentis supported by the theories expressed by Smaldino, etal (2008), product development not only in the form of instructional media, but also in the form of procedures, instruments and learning process. Mainstreaming of prototype product of blended learning model for orthopedagogic of children with physical disability course in Special Education Department that is targeted, so that it can overcome the problems faced by lecturers who have found various references and field data.

The product development is based on the utilization of information and communication technology by packaging internet or online e-learning that has been facilitated by State University of Surabaya. In addition, as part of efforts to improve student score of Special Education Department Faculty of Education, State University of Surabaya, occupy an important role in preparing graduates qualifying standard of competitive society. Another reason in development today use iternet for educational purposes more wide-spread, especially in developed countries. Indeed findings indicate that the online 
media allows the implementation of the learning process more effective.

If the undergraduate student of the Special Education Department, Faculty of Education, State University of Surabaya has difficulty understanding a part they can repeat again until they able to understand. If after repeated there are still things that have not been understood, learners can contact the instructor / resource person via e-mail or interactive dialog at certain times. E-learning, as expressed by Rusman (2011), that teachers and learners can communicate easily through internet facilities regularly or whenever communication activities are conducted with no limited by time and place. Teachers and learners can use learning materials or structured Internet learning. Wedemeyer (in Rusman, 2011) asserts that the independence of learning with e-learning programs requires learners to learn independently and autonomously.

Related to blended learning model, the relationship between teachers and learner is a central point of ed-ucation. Furthermore, the impact of the condition of infrastructure and learner is not appropriate, and the more the number of students, then the conventional method is less achieve maximum results. The result of learning study that integrates learning using computer (internet) with traditional method stated that the achievement got better with computer (internet) (Newby, et al., 2006). The best learning for students when arranged systematically can inspire, be fun and motivate, so that they can learn independently and are designed according to their grade or level.

Specifically, the learning centered on what, how and where it was appropriate for the needs of Special Education Department undergraduate students. In learning that suits the needs of students in this level is about what is taught. The principles of learning methods in the context of how learning is provided and the last is the place for learning that is in accordance with the needs of the students where learning needs to be given blended learning methods that can enrich and explore the mastery of learning material both offline and utilizing various sites available in Internet. In developing a blended learning model for orthopedagogic lectures for children with physicall disabilities in the Department of Special Education using the principles of learning methods, as follows:

- Learning that suits the learning needs of Special Education Department students.

- Lecturers emphasize learning through visual channels both offline and online.

- Learning requires real experience in learning the concept of subject matter.

The linkage of the blended learning model to the orthopedagogic lectures of children with physicall disabilities in the Department of Special Education is prioritized on the way the packaging of learning products delivered to students comprehends comprehensively the teaching material. The complexity of the characteristics and needs of children with special needs who will be served and fostered through orthopedagogic lectures of children with physicall disabilities is striving that they can participate and socialize with their environment. Because in the lecture that the blended learning model as an alternative to develop teaching materials both offline and online, this can prepare students of the Department of Special Education of the Faculty of Education of the State University of Surabaya in handling children with physicall disabilities in the field.

\section{CONCLUSION}

The development of a prototype product of the blended learning model for orthopedagogic of chil-dren with physical disability course in special educa-tion department has been designed based on the ADDDEM model. The process of developing proto-type product of teaching materials orthopedagogic of children with physical disability course in special education department based on mixed learning, through the steps, as follows a) Learning in accord-ance with the learning needs of undergraduate stu-dents majoring in special education department, b) appropriate educator of visual learning both offline and online, and c) learning requires real experience in discussing the concept of lecture materials.

\section{RECOMMENDATION}

Based on the previous conclusions, the following recommendations can be given:

- Further research is needed regarding the application of a blended learning model in a wider population

- $\quad$ The need for developing ICT-based blended learning. models in other subjects.

- The application of data analysis techniques and testing the validity of other data can also be applied.

\section{REFERENCES}

[1] A.Faisal, Efforts to Increase Student Activity through Implementation of Blended Learning at Biology Learning Class XI SMAIT Nur Hidayah Kartasura. Thesis: FKIP UNS, 2011.

[2] I.N.S. Degeng, Learning Theory and Instructional Strategy. Citra Raya: Surabaya, 2000.

[3] L.J. Cronbach, Lee J, Essentials of Psychological Testing. Fifth edition. New York: Harper and Row Publishers, 1990.

[4] M. Pramono, et al, The Development of E-Content of Virtual Learning. Surabaya: Unesa University Press, 2015.

[5] P. Setyosari, Theory and Aplication of Online System on Learning. Malang; Universitas Negeri Malang. 2005.

[6] Rusman, Learning Models: Developing Teacher's Profesionalism. PT. Raja Grafindo Persada:Jakarta, 2015.

[7] S.E. Smaldino, Lowther, L.Deborah, Russel, D.James, Instructional Technology and Media for Learning (Ninth Edition). NJ: Pearson Education Inc, 2008.

[8] S.E. Smaldino, et al, Istructional Technology And Media For Learning, Jakarta: Kencana Prenada Media Grup, 2011.

[9] T.J. Newby, et al, Educational Technology for Teaching and Learning,Upper Saddle River, NJ: Pearson Merrill Prentice Hall, 2006.

[10] Trianto. The Innovative Learning Models Oriented on Constructivism. Jakarta: Prestasi Pustaka Publisher, 2011. 